\title{
Relationship Between Acute Appendicitis and Platelet Indices in Childhood
}

\author{
Çocukluk Çağında Akut Apandisit ile Trombosit Belirteçleri Arasındaki Ilişki
}

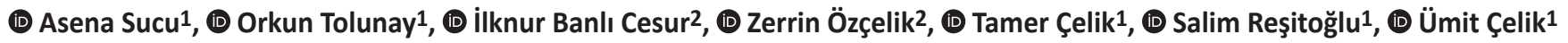 \\ ${ }^{1}$ Adana Numune Training and Research Hospital, Clinic of Pediatrics, Adana, Turkey \\ ${ }^{2}$ Adana Numune Training and Research Hospital, Pediatric Surgery, Adana, Turkey
}

\section{Abstract}

Introduction: Appendicitis is the inflammation of the appendix vermiformis. Clinical diagnosis of acute appendicitis in children is still a problem. Platelet indices, platelet distribution width and mean platelet volume have been evaluated for some infectious and inflammatory diseases. In this study, we aimed to investigate whether platelet distribution width values and mean platelet volume were decisive for the diagnosis of appendicitis in children.

Methods: In our hospital, 504 pediatric patients who presented with acute abdomen and received the diagnosis of acute appendicitis between 2011 and 2016, and 106 children living in the same region, who attended the pediatric outpatient clinics for general followup, were included in the study. The patient and control groups were analyzed for gender, age, platelet count, platelet distribution width and mean platelet volume. A receiver operating characteristic (ROC) curve was drawn to describe the parameters that may be statistically significant.

Results: There was a significant difference in platelet distribution width and mean platelet volume values between the two groups $(p<0.001)$. The platelet distribution width values were higher and the mean platelet volume values were lower in appendicitis patients than in healthy children. The ROC curve analysis suggested a cut-off value of $>14.3 \mathrm{fL}$ for platelet distribution width for the diagnosis of appendicitis with a sensitivity, specificity, positive predictive value, and negative predictive value of $77.6 \%, 85.8 \%, 96.3 \%$, and $44.6 \%$, respectively. A cut-off value of $<9.35 \mathrm{fL}$ for mean platelet volume was used for the diagnosis of appendicitis with a sensitivity, specificity, positive predictive value, and negative predictive value of $78.1 \%, 81.1 \%, 95.2 \%$, and $43.9 \%$, respectively.

Conclusion: Our results suggest that platelet distribution width and mean platelet volume may be used for the diagnosis of appendicitis in children with the sensitivity of at least $77.6 \%$ and $78.1 \%$, respectively. Mean platelet volume and platelet distribution width, which can easily be investigated in complete blood count, may serve as markers for the diagnosis of appendicitis in children, however, further large-scale studies are needed.

Keywords: Appendicitis, mean platelet volume, platelet indices, platelet distribution width

\section{Öz}

Giriş: Apandisit appendiks vermiformisin iltihaplanmasıdır. Akut apandisitin klinik tanısı çocuklarda hala bir problemdir. Trombosit indeksleri, ortalama trombosit dağılım genişliği ve trombosit hacmi, bazı enfeksiyöz ve enflamatuvar hastalıklar için değerlendirilmiştir. Bu çalışmada, çocuklarda apandisit tanısı için ortalama trombosit dağılım genişliği ve trombosit hacmi değerlerinin belirleyici olup olmadığını araştırmayı amaçladık.

Yöntemler: Hastanemizde, 2011-2016 yılları arasında akut karın nedeniyle akut apandisit tanısı alan 504 çocuk ve aynı bölgede yaşayan sağlam çocuk polikliniğine genel takip için başvuran 106 çocuk çalışmaya alındı. Hasta ve kontrol grupları cinsiyet, yaş, trombosit sayısı, ortalama trombosit dağılım genişliği ve trombosit hacmi açısından analiz edildi. Apandisitte istatistiksel olarak anlamlı olabilecek parametreleri tanımlamak için bir alıc işletim karakteristiği eğrisi [Receiver Operating Characteristic (ROC)] çizildi. Bulgular: Trombosit dağılım genişliği ve ortalama trombosit hacmi değerlerinde iki grup arasında anlamlı fark saptandı $(p<0,001)$. Apandisitli hastalarda trombosit dağılım genişliği değerleri daha yüksekti ve ortalama trombosit hacmi değerleri sağlıklı çocuklardan daha düşüktü. ROC analizi ile >14,3fL trombosit dağılım genişliği eşik değeri için, apandisit tanısında duyarlılık, özgüllük, pozitif öngörü değer ve negatif öngörü değeri sırasıyla \%77,6, \%85,8, \%96,3 ve $\% 44,6$ olarak bulunurken ortalama trombosit hacmi için <9,35 fL'lik bir eşik değer için \%78,1, \%81, \%95,2, \%43,9 olarak bulundu. Sonuç: Sonuçlarımız, çocuklarda apandisit tanısı için trombosit dağılım genişliği ve ortalama trombosit hacminin sırasıyla en az \%77,6 ve \%78,1 duyarlılık ile kullanılabileceğini düşündürmektedir. Tam kan sayımında kolaylıkla araştırılabilen ortalama trombosit hacmi ve trombosit dağılım genişliği, apandisitli çocuklarda tanısal belirteç olarak değerlendirilebilir ancak daha büyük örnek büyüklüklerine sahip çalışmalara ihtiyaç vardır.

Anahtar Kelimeler: Apandisit, ortalama trombosit hacmi, trombosit belirteçleri, trombosit dağılım genişliği

Address for Correspondence/Yazışma Adresi: Orkun Tolunay MD, Adana Numune Training and Research Hospital, Clinic of Pediatrics, Adana, Turkey E-mail: orkuntolunay@yahoo.co.uk ORCID ID: orcid.org/0000-0003-0714-6734 Received/Geliş Tarihi: 22.03.2018 Accepted/Kabul Tarihi: 26.05.2018 


\section{Introduction}

Although acute appendicitis is the most common cause of abdominal pain requiring surgery in children, clinical manifestations are often problematic. ${ }^{1}$ Laboratory tests and imaging methods, such as abdominal ultrasonography and abdominal computed tomography, are used to diagnose acute appendicitis. ${ }^{2,3}$

In recent years, platelet markers have been evaluated in the diagnosis of infectious and non-infectious inflammatory diseases. The results of these studies are controversial. Platelets are blood cells that play a role in coagulation with a life span of four to seven days. Mean platelet volume (MPV) is an indicator of both platelet function and activation. ${ }^{4}$ There is no significant difference between infant and pediatric age groups in terms of MPV. ${ }^{5}$ Platelet parameters are stable in girls and boys. They are not affected by menstrual cycles in girls. ${ }^{5,6}$ In a healthy individual, there is an inverse relationship between platelet count and MPV. ${ }^{6}$ Platelets display widespread heterogeneity in their size, density, age, and metabolic functions. ${ }^{7}$ Large platelets are more susceptible to adhesion and aggregation than small platelets. ${ }^{7}$ Diseases caused by young platelet production are associated with macrothrombocytosis due to increased destruction and immediate peripheral release of new produced cells. ${ }^{8}$ When platelets become active, MPV increases and becomes a bulging sphere with a stagnant disc shape. ${ }^{9}$

Platelet distribution width (PDW) reflects variability in the platelet size. It is used to demonstrate platelet activation such as MPV value. ${ }^{10} \mathrm{~A}$ high PDW value is indicative of increased platelet volume heterogeneity. A lower PDW value is an indication of a homogeneous platelet population. Normally, there is a linear and proportional relationship between PDW and MPV. ${ }^{11}$ The platelet indices have been determined to be useful as inflammatory markers in some diseases in assessing both disease activity and the response to treatment. 12-14 Studies examining the relationship between appendicitis and platelet indices in children are rather rare. In this study, we aimed to investigate whether PDW and MPV values are decisive for the diagnosis of appendicitis in children.

\section{Materials and Methods}

Five hundred and four pediatric patients, who were diagnosed with acute appendicitis (confirmed with pathology) at Adana Numune Training and Research Hospital between 2011 and 2016, were included in the study as the patient group (group 1). Fifty patients in the patient group were diagnosed with perforated appendicitis and encoded as group 2. One hundred and six healthy children who were followed in the pediatric outpatient clinic between 2011 and 2016 were included in the study as the control group, and encoded as group 3. The patients in the control group were living in the same region and none of them had acute or chronic diseases. Complete blood count before operation was measured on the first day of admission. Complete blood count, which includes total platelet count, white blood cell (WBC), PDW and MPV parameters, were recorded for each group. Medical records of the three groups were reviewed retrospectively. Data on age, sex, complete blood count, platelet indices and pathology results were analyzed. Complete blood count was measured in all patients using Sysmex/XN-1000 laboratory devices (Sysmex Corporation, Japan).

The study was approved by the Adana Numune Training and Research Hospital Ethics Committee (24/05/16, no: 88) and conducted in accordance with the principles of the Declaration of Helsinki. Due to the retrospective nature of this study, informed consent was waived by the ethics committee.

\section{Statistical Analysis}

Statistical analysis was performed using the Statistical Package for Social Sciences version 20 (IBM Corp., Armonk, NY, USA) statistical software package. Descriptive statistics of the variables (number, percentage, mean and standard deviation, minimum and maximum values) were calculated. Platelet indices and WBC were analyzed for diagnostic value in appendicitis by using the receiver operating characteristic (ROC) curve analysis. The area under the curve (AUC), specificity, sensitivity, positive predictive value (PPV) and negative predictive value (NPV) were calculated. Then, the accuracy of the optimal cut-off point for PDW, MPV, platelet count and WBC were calculated for appendicitis. A $p$ value of less than 0.05 was considered statistically significant.

\section{Results}

Groups 1, 2 and 3 consisted of 504, 50 and 106 patients, respectively. The mean age was $11.45 \pm 4.01$ (range: 1-18), 11.66 \pm 3.39 (range: 2-16) and $11.45 \pm 3.828$ (range: 1-18) years, respectively. There was no statistically significant difference in the age between group 1 and group 3 $(p=0.997)$ and between group 2 and group $3(p=0.744)$. The male/female proportion was $61.7 / 38.3 \%, 74 / 26 \%$ and $60.4 / 39.6 \%$, respectively. There was no statistically significant difference in sex between group 1 and group $3(p=0.827)$ and group 2 and group 3 ( $p=0.109$ ).

The mean WBC in groups 1,2 and 3 was $15.48 \pm 6.18,18.62 \pm 7.43$ and $8.28 \pm 2.47 \times 10^{3} / \mathrm{mm}^{3}$, respectively (Table 1). The mean platelet count was $291.32 \pm 83.05,286.94 \pm 92.64$ and $334.61 \pm 82.49 \times 10^{3} /$ $\mathrm{mm}^{3}$, respectively (Table 1). The mean MPV value was $7.9235 \pm 1.64 \mathrm{fL}, 8.24 \pm 1.76$ and $10.08 \pm 1.28 \mathrm{fL}$, respectively (Table 
1). In addition, the mean PDW value was $16.01 \pm 2.93 \mathrm{fL}, 15.28$ 3.39 and $12.29 \pm 2.30 \mathrm{fL}$, respectively (Table 1).

ROC curve was plotted to identify the parameters that can be statistically significant in appendicitis. For MPV, the calculated AUC was $84.1 \%$. When the MPV was below $9.35 \mathrm{fL}$, sensitivity and specificity were $78.1 \%$ and $81.1 \%$, and PPV and NPV were $95.2 \%, 43.9 \%$, respectively (Table 2, Figure 1). For PDW, the AUC was $81.4 \%$ and the cut-off value was higher than 14.3 , sensitivity and specificity were $77.6 \%$ and $85.8 \%$, and PPV and NPV were $96.3 \%, 44.6 \%$, respectively (Table 2 , Figure 2). On the other hand, platelet count was higher than $313.50 \times 10^{3} / \mathrm{mm}^{3}$, sensitivity and specificity were $66.2 \%$ and $59.4 \%$, respectively (Table 2, Figure 1 ). The AUC was $87 \%$ for WBC count and the cut-off value was higher than $9.29 \times 10^{3} /$ $\mathrm{mm}^{3}$, sensitivity and specificity were $83.7 \%$ and $72.6 \%$, and

\begin{tabular}{|c|c|c|c|}
\hline Characteristics & $\begin{array}{l}\text { Group } 1-2 \\
n=504-50 \\
\text { Mean } \pm \\
\text { standard } \\
\text { deviation }\end{array}$ & $\begin{array}{l}\text { Group } 3 \\
\text { (Control group) } \\
\mathrm{n}=106 \\
\text { Mean } \pm \\
\text { standard } \\
\text { deviation }\end{array}$ & p-value \\
\hline $\begin{array}{l}\text { MPV* (fL) } \\
\text { Group } 1 \\
\text { Group } 2\end{array}$ & $\begin{array}{l}7.92 \pm 1.64 \\
8.24 \pm 1.76\end{array}$ & $\begin{array}{l}10.08 \pm 1.28 \\
10.08 \pm 1.28\end{array}$ & $\begin{array}{l}<0.001 \\
<0.001\end{array}$ \\
\hline $\begin{array}{l}\text { PDW** (fL) } \\
\text { Group } 1 \\
\text { Group } 2\end{array}$ & $\begin{array}{l}16.01 \pm 2.93 \\
15.28 \pm 3.39\end{array}$ & $\begin{array}{l}12.29 \pm 2.3 \\
12.29 \pm 2.3\end{array}$ & $\begin{array}{l}<0.001 \\
<0.001\end{array}$ \\
\hline $\begin{array}{l}\text { Platelet count }\left(10^{3} / \mathrm{mm}^{3}\right) \\
\text { Group } 1 \\
\text { Group } 2\end{array}$ & $\begin{array}{l}291.32 \pm 83.05 \\
286.94 \pm 92.64\end{array}$ & $\begin{array}{l}334.61 \pm 82.49 \\
334.61 \pm 82.49\end{array}$ & $\begin{array}{l}<0.001 \\
<0.001\end{array}$ \\
\hline $\begin{array}{l}\text { White blood cell }\left(10^{3} / \mathrm{mm}^{3}\right) \\
\text { Group } 1 \\
\text { Group } 2\end{array}$ & $\begin{array}{l}15.48 \pm 6.18 \\
18.62 \pm 7.43\end{array}$ & $\begin{array}{l}8.28 \pm 2.47 \\
8.28 \pm 2.47\end{array}$ & $\begin{array}{l}<0.001 \\
<0.001\end{array}$ \\
\hline
\end{tabular}

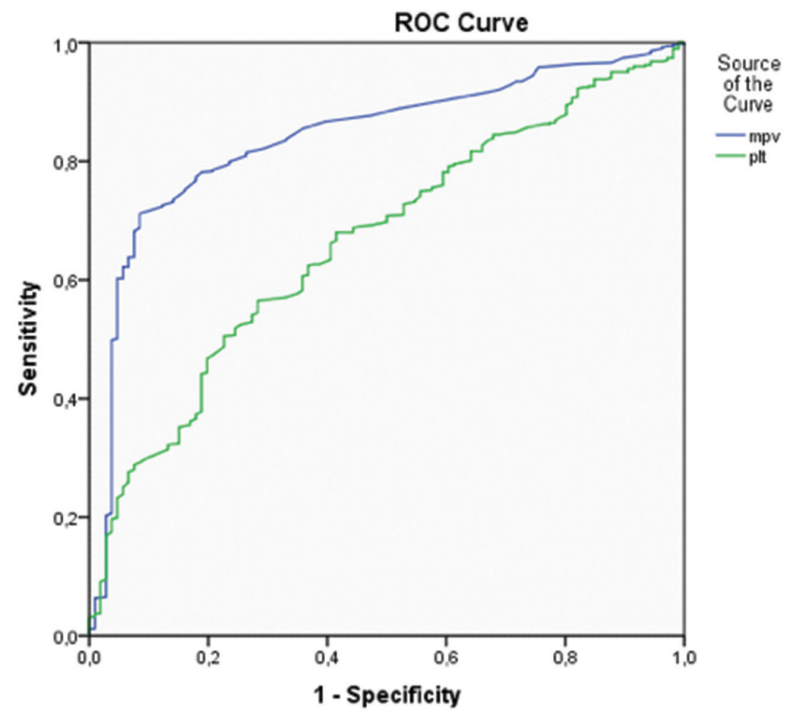

Figure 1. Receiver operating characteristic curve for mean platelet volume and platelet

MPV: Mean platelet volume, PLT: Platelet
PPV and NPV were $93.4 \%$ and $48.1 \%$, respectively (Table 2 , Figure 2).

\section{Discussion}

MPV and PDW parameters can be easily examined using routine complete blood count analysis. MPV is a parameter which reflects the platelet size and provides information on platelet function and activation. The size of circulating platelets provides information about the intensity of inflammation. PDW reflects the difference in platelet dimensions. ${ }^{12}$

MPV has been determined to be useful as an inflammatory marker in some chronic diseases in assessing disease activity and response to treatment. ${ }^{13,14}$ Two important changes, such as an increase in platelet count in the course of infectious diseases and a decrease in MPV, were first reported in a study by Robbins and Barnard' 15 in 1983.

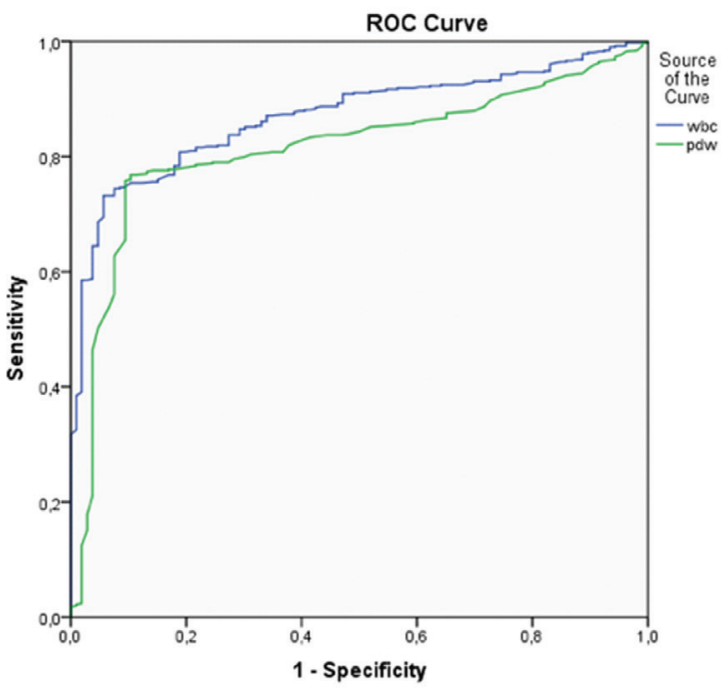

Figure 2. Receiver operating characteristic curve for platelet distribution width and white blood cell

PDW: Platelet distribution width, WBC: white blood cell

Table 2. Results of receiver operating characteristic analysis for markers in predicting group 1 compared to group 3

\begin{tabular}{|c|c|c|c|c|c|c|c|}
\hline & 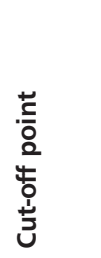 & 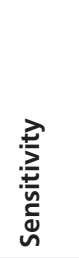 & 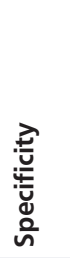 & à & 京 & ૫ૅ & 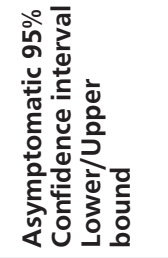 \\
\hline$M P V *(f L)$ & $<9.35$ & 78.1 & 81.1 & 95.2 & 43.9 & 0.841 & $0.801 / 0.880$ \\
\hline PDW** \% & $>14.3$ & 77.6 & 85.8 & 96.3 & 44.6 & 0.814 & $0.774 / 0.855$ \\
\hline $\begin{array}{l}\text { Platelets } \\
\left(\mathrm{mm}^{3}\right)\end{array}$ & $>313.5$ & 66.2 & 59.4 & & & 0.665 & $0.612 / 0.718$ \\
\hline $\begin{array}{l}\text { White blood } \\
\text { cell }\left(\mathrm{mm}^{3}\right)\end{array}$ & $>9.29$ & 83.7 & 72.6 & 93.4 & 41.8 & 0.870 & $0.840 / 0.900$ \\
\hline
\end{tabular}


In the literature review, MPV values are different for various infectious diseases. In particular, upper respiratory tract infections, gastrointestinal tract infections and bone infections may have different effects on platelet count and function. ${ }^{16}$

In a study which investigated the relationship between acute appendicitis and MPV in children, MPV was found to be lower in patients with acute appendicitis than in controls. ${ }^{17}$ These findings were similar to the studies conducted in 2011 and 2014. ${ }^{18,19}$ Our findings are similar to those found in a systematic review conducted in 2016 (MPV was lower in acute appendicitis compared to the healthy controls). ${ }^{20}$ In contrast to these studies, there are two studies which found no MPV involvement in children with acute appendicitis. ${ }^{21,22}$ Both of these two studies were conducted with fewer patients than in our study. ${ }^{21,22}$ The sample size of these studies may be the cause of different MPV results. As new studies are conducted and the sample sizes increases, cross-sectional errors will decrease for MPV results.

In our study, platelet count was significantly lower in the patient group than in the control group. However, the values in the groups were within the normal range. The platelet counts were also within the normal range in a similar study. ${ }^{23}$ Thus, we think that platelet count is insufficient for a clinical decision of acute appendicitis. PDW values were significantly higher in the patient group than in the control group. ${ }^{23,24}$ There are studies which found similar results and opposite results with our study. ${ }^{23-25}$

It is known that WBC values are frequently elevated in patients with acute appendicitis. ${ }^{23,26}$ In our study, WBC count was significantly higher in the acute appendicitis group. Nevertheless, high WBC values alone are insufficient as a diagnostic tool in patients with appendicitis. When WBC, platelet count, MPV and PDW values in patients with perforated appendicitis were compared with those in healthy subjects, the results were similar to those in acute appendicitis patients.

When we evaluate previous studies which examined platelet indices in pediatric appendicitis, our study is the largest study demonstrating the relationship between acute pediatric appendicitis and platelet markers. ${ }^{21,22}$ On the other hand, there are a limited number of studies investigating the relationship between acute appendicitis in childhood and platelet markers. Moreover, the results of these studies are controversial.

\section{Conclusion}

In conclusion, the results of our study suggest that PDW and MPV may be used for the diagnosis of appendicitis in children with the sensitivity of at least $77.6 \%$ and $78.1 \%$, respectively. In addition, the sensitivity of leukocyte count is higher than that of platelet indices. MPV and PDW, which can easily be investigated in complete blood count, may serve as markers for the diagnosis of appendicitis in children, however, further large-scale studies are warranted.

\section{Ethics}

Ethics Committee Approval: The study was approved by the Adana Numune Training and Research Hospital Ethics Committee (24/05/16, no: 88) and conducted in accordance with the principles of the Declaration of Helsinki.

Informed Consent: Due to the retrospective nature of this study, informed consent was waived by the ethics committee.

\section{Authorship Contributions}

Surgical and Medical Practices: I.B.C., Z.Ö., Concept: A.S., Ü.Ç., T.Ç., O.T., Design: A.S., I.B.C., Z.Ö., O.T., Data Collection or Processing: I.B.C., Z.Ö. O.T., S.R., Analysis or Interpretation: Ü.Ç., O.T., T.Ç., Literature Search: O.T., S.R., T.Ç., A.S., Writing: A.S., Ü.Ç., O.T.

Conflict of Interest: No conflict of interest was declared by the authors.

Financial Disclosure: The authors declared that this study received no financial support.

\section{References}

1. Karabulut R, Sönmez K, Türkyılmaz Z, Demiroğulları B, Ozen IO, et al. Negative appendectomy experience in children. Ir J Med Sci. 2011;180:55-58

2. Lessin MS, Chan M, Catallozzi M, Gilchrist MF, Richards C, et al. Selective use of ultrasonography for acute appendicitis in children. Am J Surg. 1999;177:193-196.

3. Andersson M, Andersson RE. The appendicitis inflammatory response score: a tool for the diagnosis of acute appendicitis that out performs the Alvarado score. World J Surg. 2008;32:18431849.

4. Bath PM, Butterworth RJ. Platelet size: Measurement, physiology and vascular disease. Blood Coagul Fibrinolysis. 1996; 7: 157-161.

5. Bancroft AJ, Abel W, Mclaren M, Belch JJ. Mean trombosit volume is a useful parameter: are producible routine method using a modified Coulter Thrombocytometer. Platelets. 2000;11:379-387.

6. Jackson SR, Carter JM. Platelet volume: laboratory measurement and clinical application. Blood Rev. 1993;7:104-113.

7. Şenaran $H$, ileri $M$, Altınbaş $A$, Koşar $A$, Yetkin $E$, et al. Thrombopoietin and mean trombosit volume in coronary artery disease. Clin Cardiol. 2001;24:405-408.

8. Paulus JM. 1975. Trombosit size in man. Blood. 1997;46:321-334.

9. Park $Y$, Schoene $N$, Harris W. Mean platelet volume as an indicator of platelet activation: methodological issues. Platelets. 2002;13:301-6.

10. Soydinc S, Turkbeyler IH, Pehlivan $Y$, Soylu G, Goktepe MF, et al. Mean platelet volume seems to be a valuable marker in patients with systemic sclerosis. Inflammation. 2014;37:100-6. 
11. Çelik Ü, Çelik T, Tolunay O, Dönmezer Ç, Gezercan Y, et al. The platelet indices in diagnosis of ventriculoperitoneal shunt infection in children. Turk Neurosurg. 2017;27:590-593.

12. De Luca G, Venegoni L, lorio S, Secco GG, Cassetti E, et al. Platelet distribution width and the extent of coronary artery disease: results from a large prospective study. Platelets. 2010;21:508-14.

13. Kapsoritakis AN, Koukourakis MI, Sfiridaki A, Potamianos SP, Kosmadaki MG, et al. Mean platelet volume: a useful marker of inflammatory bowel disease activity. Am J Gastroenterol. 2001;96:776-781.

14. Purnak T, Olmez S, Torun S, Efe C, Sayilir A,et al. Mean platelet volume is increased in chronic hepatitis $C$ patients with advanced fibrosis. Clin Res Hepatol Gastroenterol. 2013;37:41-46.

15. Robbins G, Barnard DL. Mean platelet volume changes in infection. J Clin Pathol. 1983;36:1320.

16. Marwaha N. Thrombocytosis as a predictor of serious bacterial infection. Indian Pediatr. 2010;47:923-4.

17. Bilici S, Sekmenli T, Göksu M, Melek M, Avcı V. 2011. Mean platelet volume in diagnosis of acute appendicitis in children. Afr Health Sci. 2011;11:427-432.

18. Albayrak Y, Albayrak A, Albayrak F, Yildirim R, Aylu B, et al. Mean platelet volume: a new predictor in confirming acute appendicitis diagnosis. Clin Appl Thromb Hemost. 2011;17:362-6.

19. Tanrikulu CS, Tanrikulu Y, Sabuncuoglu MZ, Karamercan MA, Akkapulu N, et al. Mean platelet volume and red cell distribution width as a diagnostic marker in acute appendicitis. Iran Red Crescent Med J. 2014;16:e10211.

20. Budak YU, Polat M, Huysal K. The use of platelet indices, plateletcrit, mean platelet volume and platelet distribution width in emergency non-traumatic abdominal surgery: a systematic review. Biochem Med (Zagreb). 2016;26:178-93.

21. Uyanik B, Kavalcı C, Arslan ED, Yılmaz F, Arslan O, et al. Role of mean platelet volume in diagnosis of childhood acute appendicitis. Clinical Study. 2012;2012:823095.

22. Erdağ $\mathrm{GÇ,} \mathrm{Coşkun} \mathrm{FT,} \mathrm{Biçer} \mathrm{S}$, Uğraş M, Giray T, et al. Can Mean Platelet Volume be Used as a Marker in Children with Acute Appendicitis? J Ped Emerg Intensive Care Med. 2017;4:17-21.

23. Boshnak N, Boshnaq M, Elgohary $\mathrm{H}$. Evaluation of Platelet Indices and Red Cell Distribution Width as New Biomarkers for the Diagnosis of Acute Appendicitis. J Invest Surg. 2017;16:1-9.

24. Aydoğan A, Akkucuk S, Arica S, Motor S, Karakus A, et al. The analysis of mean platelet volume and plateletdistribution width levels in appendicitis. Indian J Surg. 2015;77:495-500.

25. Yılmaz Y, Kara F, Gümüşdere $M$, Arslan H, Üstebay $S$. The platelet indices in pediatric patients with acute appendicitis. Int J Res Med Sci. 2015;3:1388-139.

26. Shogilev DJ, Duus N, Odom SR, Shapiro NI. Diagnosing appendicitis: evidence-based review of the diagnostic approach in 2014. West J Emerg Med. 2014;15:859-71. 